Original Article

\title{
Mathematical models to describe the growth curves of Vietnamese Ri chicken
}

\author{
Modelos matemáticos para descrever as curvas de crescimento do frango Ri \\ vietnamita
}

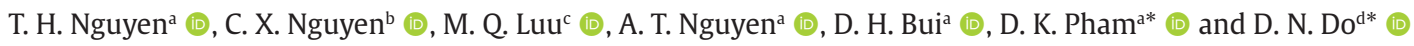

aFaculty of Animal Science, Vietnam National University of Agriculture, Hanoi, Vietnam

bFaculty of Biotechnology, Vietnam National University of Agriculture, Hanoi, Vietnam

'Ministry of Science and Technology, Hanoi, Vietnam

dDepartment of Animal Science and Aquaculture, Dalhousie University, Truro, Canada

\begin{abstract}
Ri chicken is the most popular backyard chicken breed in Vietnam, but little is known about the growth curve of this breed. This study compared the performances of models with three parameters (Gompertz, Brody, and Logistic) and models containing four parameters (Richards, Bridges, and Janoschek) for describing the growth of Ri chicken. The bodyweight of Ri chicken was recorded weekly from week 1 to week 19. Growth models were fitted using minpack.lm package in R software and Akaike's information criterion (AIC), Bayesian information criterion (BIC), and root mean square error (RMSE) were used for model comparison. Based on these criteria, the models having four parameters showed better performance than the ones with three parameters, and the Richards model was the best one for males and females. The lowest and highest value of asymmetric weights $(\alpha)$ were obtained by Bridges and Brody models for each of sexes, respectively. Age and weight estimated by the Richard model were 8.46 and 7.51 weeks and 696.88 and $487.58 \mathrm{~g}$ for males and for females, respectively. Differences in the growth curves were observed between males and female chicken. Overall, the results suggested using the Richards model for describing the growth curve of Ri chickens. Further studies on the genetics and genomics of the obtained growth parameters are required before using them for the genetic improvement of Ri chickens.
\end{abstract}

Keywords: chicken, growth curve, body weight, Vietnam, indigenous breeds.

\begin{abstract}
Resumo
O frango Ri é a raça de frango de quintal mais popular do Vietnã, mas pouco se sabe sobre a curva de crescimento dessa raça. Este estudo comparou o desempenho de modelos com três parâmetros (Gompertz, Brody e Logistic) e modelos contendo quatro parâmetros (Richards, Bridges e Janoschek) para descrever o crescimento do frango Ri. O peso corporal do frango Ri foi registrado semanalmente da semana 1 à semana 19. Os modelos de crescimento foram ajustados usando o pacote minpack.lm no software R e o critério de informação de Akaike (AIC); critério de informação bayesiano (BIC) e erro quadrático médio (RMSE) foram usados para comparação de modelos. Com base nesses critérios, os modelos com quatro parâmetros apresentaram melhor desempenho do que os com três parâmetros, sendo o modelo de Richards o melhor para homens e mulheres. O menor e o maior valor dos pesos assimétricos $(\alpha)$ foram obtidos pelos modelos Bridges e Brody para cada um dos sexos, respectivamente. A idade e 0 peso estimados pelo modelo de Richard foram de 8,46 e 7,51 semanas e 696,88 e 487,58 g para homens e mulheres, respectivamente. Diferenças nas curvas de crescimento foram observadas entre frangos machos e fêmeas. No geral, os resultados sugeriram o uso do modelo de Richards para descrever a curva de crescimento de frangos Ri. Mais estudos sobre a genética e genômica dos parâmetros de crescimento obtidos são necessários antes de usá-los para o melhoramento genético de frangos Ri.
\end{abstract}

Palavras-chave: galinha, curva de crescimento, peso corporal, Vietnã, raças indígenas.

\section{Introduction}

Chickens (Gallus gallus domesticus) are domesticated nearly 10,000 years ago (Sawai et al., 2010), and they contribute significantly to agricultural products in many countries. In Vietnam, chickens play an essential role in agricultural production as the primary source of eggs and meat. Chickens also have a vital role in Vietnamese cultures as they are used for many festivals and cultural events. According to the FAO (2020), Vietnam has at least

*e-mail: pkdang@vnua.edu.vn

Received: March 12, 2021 - Accepted: June 28, 2021

This is an Open Access article distributed under the terms of the Creative Commons Attribution License, which permits unrestricted use, distribution, and reproduction in any medium, provided the original work is properly cited. 
16 different local breeds. In recent studies, BerthoulySalazar et al. (2010) and Pham et al. (2013) listed about 30 local chicken populations/breeds across different regions in Vietnam. Among these breeds, Ri chicken is the most popular chicken breed in Vietnam's rural areas (Moula et al., 2011). The Ri chickens have more than 129 million individuals and represent about 85\% of the local chickens (Thuy and Vang, 2002). This breed is also well recognized by the Vietnamese as a yellowed feathered breed (Su et al., 2004). Raising Ri chicken is also an important economic activity for many farmers in Vietnam as the chickens are a significant source of income for their families. Understanding local breeds' growth could make contributions to nutrition, management, and breeding, and therefore increase productivity (Thornton, 2010; Padhi, 2016; Ibeagha-Awemu et al., 2019). The local breeds often have better disease resistance and better adaptation to harsh environment conditions than the highly commercialized breeds which could be used as the generic resources for future. Especially, the local customers in Vietnam often prefer the meat from the local breeds such as Ri than the meat from imported and commercially raised chicken breeds. However, little is known about the growth performance of Ri chicken.

In livestock, growth is simply considered as any change in body size such as weight or length time unit and is known to be a quantitative trait (Narinç et al., 2017). Understanding animal growth is important for optimal feeding management and genetics improvement (Narinç et al., 2017; Do and Miar, 2019). Non-linear models have been intensively used to characterize the growth in different livestock species. The Gompertz, Brody, Logistic, Bridges, Janoschek, and Richards are among the most common linear models for describing the growth curves (Narinc et al., 2010; Darmani Kuhi et al., 2010, Sariyel et al., 2017, Kaplan and Gürcan, 2018; Iqbal et al., 2019; Wellock., 2004). The growth curve of the different indigenous chicken breeds has been studied many countries (OseiAmponsah et al., 2014), (Rizzi et al., 2013; Selvaggi et al., 2015). This information is important for improving the local chicken breeds' genetic and feeding strategies (Selvaggi et al., 2015). In Vietnam, the Gompertz model recently reported a best model to describe the growth curve in Mia chicken compared to the Richards, Logistic, and Bridges models (Nguyen Hoang et al., 2021). Therefore, this study compared six different growth models (Gompertz, Brody, Logistic, Richards, Bridges, and Janoschek) for describing growth pattern of Ri chicken in Vietnam.

\section{Materials and Methods}

\subsection{Resource population}

A total of 103 (46 males and 57 females) unrelated chicken was used in the current study. They were raised in floor pens at the Breeding Center of the Vietnam National University of Agriculture. The chickens were accessed to food (commercial corn-soybean diets (Table 1)) and water ad libitum. The food ingredients for each growth period were adjusted according to the guidelines of the Vietnamese
Table 1. The commercial corn-soybean diets according to three different growth periods.

\begin{tabular}{cccc}
\hline Diets & $\begin{array}{c}\text { Week } \\
\mathbf{0 - 4}\end{array}$ & $\begin{array}{c}\text { Week } \\
\mathbf{5 - 8}\end{array}$ & $\begin{array}{c}\text { Week } \\
\mathbf{9 - 2 1}\end{array}$ \\
\hline Gross energy (Kcal/kg) & 2900 & 3000 & 2850 \\
Protein (\%) & 20.0 & 18.0 & 16.0 \\
Ash (\%) & 5.0 & 5.0 & 5.0 \\
Calcium (\%) & 0.9 & 0.85 & 0.85 \\
Phosphorus (\%) & 1.1 & 0.8 & 0.8 \\
Methionine + Cystine (\%) & 0.75 & 0.7 & 0.7 \\
Lysine (\%) & 1.0 & 0.8 & 0.85 \\
\hline
\end{tabular}

National Research Council requirement. Animals were weighed each week individually from week 1 to week 19. There are no specific laws regarding Animal Welfare in Vietnam; therefore, we also adapted the guidelines of using animals in research based on EU directive 2010/63 for the best practice during sample collection.

\subsection{Growth modelling and evaluations}

A total of six different growth models, which included three three-parameters models (Gompertz, Brody, and Logistic) and three four-parameter models (Richards, Bridges, and Janoschek), were used for modeling of growth curves in males and females separately (Table 2). Similar methods were applied for fitting models, as described by Nguyen Hoang et al. (2021). In brief, the body weight (BW) was fitted as a function of time (week) using nlsLM() command in minpack.lm packages (implementing the Levenberg-Marquardt algorithm) (Elzhov et al., 2016) in R software (R Development Core Team, 2011). The Akaike's information criterion (AIC), Bayesian information criterion (BIC), and root mean square error (RMSE) were used for comparison of fitted models and selection of the best model to describe the growth curve in males and females. The AIC (equation 1) and BIC (equation 2) were defined as

$$
\begin{aligned}
& A I C=-2 \log -\text { Likelihood }+2 K \\
& B I C=-2 \log -\text { Likelihood }+K \times N
\end{aligned}
$$

where log-Likelihood is the maximum likelihood, $\mathrm{K}$ is the number of parameters in the model, and $\mathrm{N}$ is the sample size.

The RMSE of a model prediction with respect to the estimated variable $X_{\text {model }}$ is defined as the square root of the mean squared error (equation 3 ):

$$
R M S E=\sqrt{\frac{\sum_{i=1}^{n}\left(X_{o b s, i}-X_{\text {model }, i}\right)^{2}}{n}}
$$


Table 2. Growth models used in the study.

\begin{tabular}{|c|c|c|c|c|}
\hline Model & Equation & Parameters & Age at inflection & Weight of inflection \\
\hline Logistic & $\mathrm{BWt}=\frac{a}{\beta \times\left(1+e^{-k t}\right)}$ & $\alpha, \beta$ and $\mathrm{k}$ & $\alpha / 2$ & $-\ln (1 / \beta) / \mathrm{k}$ \\
\hline Gompertz & $\mathrm{BWt}=a \times e^{-\beta \times e^{-k t}}$ & $\alpha, \beta$ and $\mathrm{k}$ & $\alpha / \mathrm{e}$ & $\ln (\beta) / \mathrm{k}$ \\
\hline Brody & $\mathrm{BWt}=a \times\left(1-\beta \times e^{-k t}\right)$ & $\alpha, \beta$ and $\mathrm{k}$ & & \\
\hline Bridges & $\mathrm{BWt}=\mathrm{BW}_{0}+a \times\left(1-e^{-k t^{m}}\right)$ & $\alpha, \mathrm{BW}_{0}, \mathrm{k}$ and $\mathrm{m}$ & - & - \\
\hline Janoschek & $\mathrm{BWt}=a-\left(a-\mathrm{BW}_{0}\right) \times e^{-k t^{m}}$ & $\alpha, \mathrm{BW}_{0}, \mathrm{k}$ and $\mathrm{m}$ & - & - \\
\hline Richards & $\mathrm{BWt}=\frac{a}{\left(1-\beta \times e^{-k t}\right)^{\frac{1}{m}}}$ & $\alpha, \beta, \mathrm{k}$ and $\mathrm{m}$ & $\frac{a}{(m+1)^{\frac{1}{m}}}$ & $-\ln (\mathrm{m} / \beta) / \mathrm{k}$ \\
\hline
\end{tabular}

$\mathrm{BW}_{\mathrm{t}}$-body weight in $\mathrm{kg}$ at the time $\mathrm{t} ; \mathrm{BW}$-initial body weight in $\mathrm{kg} ; \alpha-$ mature body weight in $\mathrm{g} ; \mathrm{t}$-age in weeks; $\beta, \mathrm{k}$, and $\mathrm{m}-\mathrm{parameters}$ specific for the function; $\beta$ characterizes the first part of growth before the point of inflection; $k$ describes the second part in which growth rate decreases until the animal reaches the asymptotic or mature weight $(\alpha), \mathrm{m}$ is the shape parameter determining the position of the curve point inflection.

where $X_{\text {obs }}$ is observed values, and $X_{\text {model }}$ is modelled values at time/place $i$.

The accuracy was calculated based on the Pearson's correlations between the actual BW and the predicted BW in R software (R Development Core Team, 2011).

\section{Results and Discussion}

The descriptive statistics of body weight in different ages for males and females are shown in Table 3. The BW increased from 25.74 to $1522.61 \mathrm{~g}$ in males and from 25.67 to $1124.2 \mathrm{~g}$ in females, respectively. Males always have higher BW than females (Figure 1). The coefficients of variation were varied among weeks, with the highest values at week 5 or 6 for males and females. Table 4 shows the value of AIC, BIC, and RMSE criteria for each model. Based on the AIC, BIC, and RMSE criteria, the four-parameter models have better performance (lower values) than the three-parameter models in both sexes. The Brody model was the worst model as it had the highest AIC in both males (11193.74) and females (13389.22). The Richards model was the best model in the male as it had the lowest AIC values in males $($ AIC $=10596.39)$ and females $($ AIC $=12750.89)$. A similar trend of AIC was also observed for BIC. A similar trend was also observed when using the RMSE as a criterion since the Richards models had the lowest value and the Brody had the highest value. Pearson's correlations between the predicted BW and actual BW were high for all models as the values of correlations were always higher than 0.99 . The lowest and highest correlation values were for Brody and Richard models, respectively. The actual BW and the growth curves from the best (Richard) and the worst (Brody) models for male and female Ri chickens are shown in Figure 1. The models having four parameters were better than the ones with three parameters, which might be due to the flexibility of choosing the inflection point in the four parameters models. These results were also observed in other studies in chicken (Narinç et al., 2017). In addition, we also observed inconsistency in the ranking of the goodness of fit in Ri chicken in the current study compared to our previous research in the Mia chicken (Nguyen Hoang et al., 2021). Previously, the Gompertz model and Bridges models were the best models in males and females Mia chicken, respectively (Nguyen Hoang et al., 2021), but were not in the current study. This inconsistency is possibly due to the sample size, genetics, and management. The outperformance of Richards models has been observed in many different studies (Kaplan and Gürcan, 2018), while the better performance of the Gompertz model among three-parameter models was also reported (Aggrey 2002; Rizzi et al., 2013; Zhao et al., 2015). Similar performance of the Bridges and Janoschek models has been reported previously in goat and mink(García-Muñiz et al., 2019; Do and Miar, 2019). Expectedly, the Brody model was the worst model in males and females to describe the growth curve. Therefore, this model should not be used for describing the growth of Ri chicken. Nevertheless, despite the variety of existing growth models, the Richards model could be used for the evaluation of the growth curve in $\mathrm{Ri}$ chickens. Recently, the growth parameters of the Richards model were reported as heritable (Do et al., 2021), so they can be used in genetic or genomic prediction programs.

Table 5 presents the estimated growth parameters for Ri chicken using six models. Estimated asymmetric weights $(\alpha)$ ranged from $1480.59 \pm 14.66 \mathrm{~g}$ (Bridges model) to $3238.72 \pm 186.76 \mathrm{~g}$ (Brody model) for male and from $1101.95 \pm 10.16 \mathrm{~g}$ (Bridges model) and $1813.03 \pm 50.88 \mathrm{~g}$ (Brody model) for females, respectively. Both males and females had similar mature growth rates ( $\mathrm{k}$ ) across the models, with the highest values in the Logistic model and the lowest values in the Janoschek model. The other parameters, including $\beta$ and the shape parameters value ( $m$ ), fluctuated among models and sexes. The females had lower estimated 

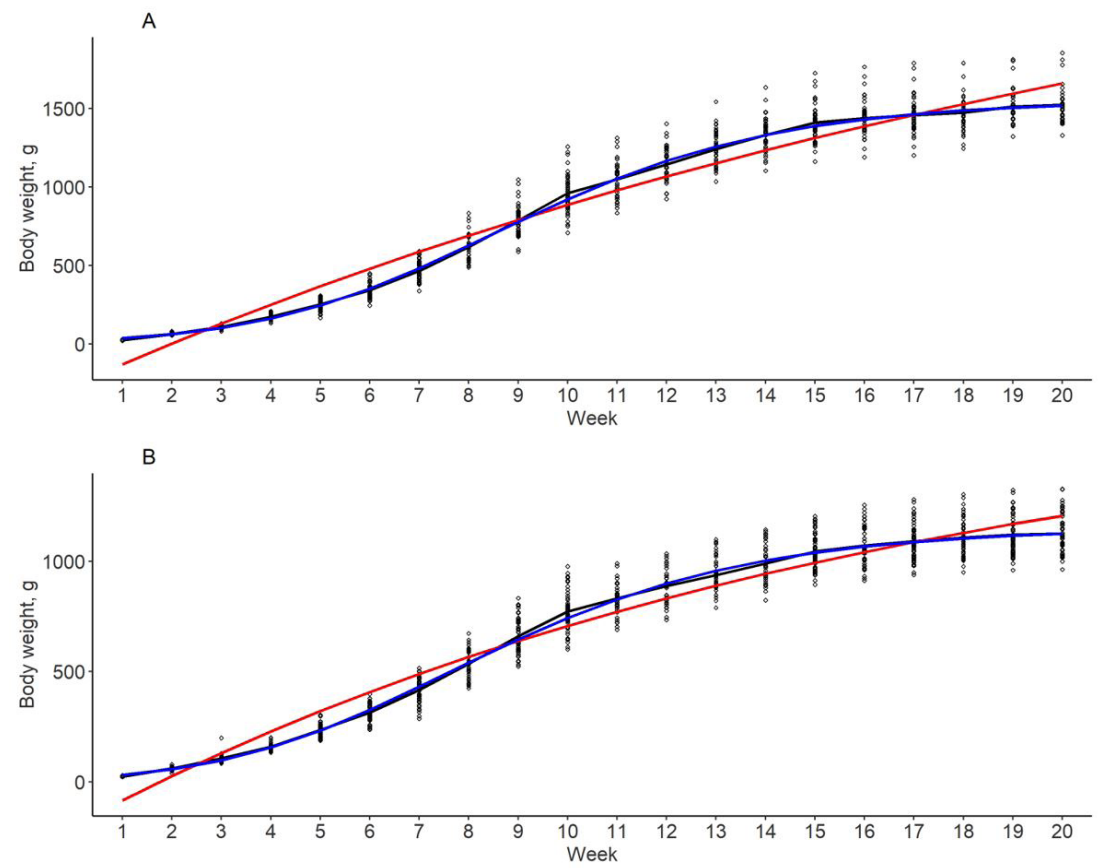

Figure 1. The growth curve of male and female Ri chickens for the best and the worst model in male (A) and female (B) chickens. The black dots indicate the bodyweights of each chicken. The black, blue, and red lines show the mean of actual bodyweights and the growth curve of the best (Richards) and the worst (Brody) model, respectively.

Table 3. Descriptive statistics of body weight in different ages for male and females.

\begin{tabular}{|c|c|c|c|c|c|c|c|c|}
\hline \multirow[b]{2}{*}{ Week } & \multicolumn{4}{|c|}{ Male } & \multicolumn{4}{|c|}{ Female } \\
\hline & $\mathbf{N}$ & $\begin{array}{c}\text { BW }(\mathrm{g}) \\
(\text { Mean } \pm \text { SE) }\end{array}$ & SD & $\begin{array}{l}\text { CV } \\
(\%)\end{array}$ & $\mathbf{N}$ & $\begin{array}{c}\text { BW }(g) \\
(M e a n \pm S E)\end{array}$ & SD & $\begin{array}{l}\text { CV } \\
(\%)\end{array}$ \\
\hline $0^{*}$ & 46 & $25.74 \pm 0.31$ & 2.09 & 8.12 & 57 & $25.67 \pm 0.24$ & 1.8 & 7.01 \\
\hline 1 & 44 & $63.44 \pm 0.91$ & 6.03 & 9.51 & 57 & $61.01 \pm 0.89$ & 6.72 & 11.01 \\
\hline 2 & 45 & $110.37 \pm 1.8$ & 12.06 & 10.93 & 55 & $107 \pm 2.25$ & 16.65 & 15.56 \\
\hline 3 & 45 & $173.12 \pm 3.06$ & 20.52 & 11.85 & 56 & $160.18 \pm 20$ & 14.96 & 9.34 \\
\hline 4 & 45 & $252.94 \pm 4.71$ & 31.58 & 12.49 & 57 & $235.03 \pm 3.34$ & 25.24 & 10.74 \\
\hline 5 & 46 & $344.07 \pm 6.79$ & 46.04 & 13.38 & 57 & $314.7 \pm 4.94$ & 37.28 & 11.85 \\
\hline 6 & 46 & $465.68 \pm 9.14$ & 62.01 & 13.32 & 56 & $417.22 \pm 7.14$ & 53.47 & 12.82 \\
\hline 7 & 46 & $617.84 \pm 11.81$ & 80.13 & 12.97 & 57 & $535.99 \pm 7.94$ & 59.91 & 11.18 \\
\hline 8 & 46 & $786.32 \pm 14.22$ & 96.46 & 12.27 & 57 & $659.89 \pm 9.54$ & 72.01 & 10.91 \\
\hline 9 & 46 & $960.91 \pm 18.01$ & 122.15 & 12.71 & 57 & $772.55 \pm 11.23$ & 84.82 & 10.98 \\
\hline 10 & 46 & $1048.67 \pm 17.22$ & 116.8 & 11.14 & 57 & $830.75 \pm 10.02$ & 75.63 & 9.10 \\
\hline 11 & 46 & $1144.95 \pm 16.79$ & 113.89 & 9.95 & 57 & $886.84 \pm 9.71$ & 73.29 & 8.26 \\
\hline 12 & 46 & $1240.53 \pm 16.46$ & 111.63 & 9.00 & 57 & $936.69 \pm 9.67$ & 72.99 & 7.79 \\
\hline 13 & 46 & $1331.87 \pm 15.54$ & 105.4 & 7.91 & 57 & $989.59 \pm 10.06$ & 75.98 & 7.68 \\
\hline 14 & 46 & $1410.78 \pm 16.57$ & 112.4 & 7.97 & 57 & $1043.33 \pm 10.66$ & 80.47 & 7.71 \\
\hline 15 & 46 & $1436.92 \pm 16.15$ & 109.51 & 7.62 & 57 & $1069.82 \pm 11.13$ & 84.05 & 7.86 \\
\hline 16 & 46 & $1457.76 \pm 16.48$ & 111.8 & 7.67 & 57 & $1090.28 \pm 11.18$ & 84.42 & 7.74 \\
\hline 17 & 45 & $1474.44 \pm 16.85$ & 113.01 & 7.66 & 57 & $1106.37 \pm 11.23$ & 84.79 & 7.66 \\
\hline 18 & 36 & $1512.03 \pm 18.47$ & 110.81 & 7.33 & 57 & $1119.06 \pm 11.54$ & 87.15 & 7.79 \\
\hline 19 & 36 & $1522.61 \pm 18.93$ & 113.57 & 7.46 & 56 & $1124.2 \pm 11.79$ & 88.2 & 7.85 \\
\hline
\end{tabular}

*Week 0 is the first day of birth. N: Number of animals, BW: Bodyweight; CV: Coefficient of variation, SE: Standard errors of the mean, SD: Standard deviation. 
Table 4. The goodness of fit criteria for fitted models in males and females.

\begin{tabular}{|c|c|c|c|c|c|c|c|c|c|}
\hline \multirow{2}{*}{ Model } & \multirow{2}{*}{$\begin{array}{l}\text { Degree of } \\
\text { freedom }\end{array}$} & \multicolumn{4}{|c|}{ Male } & \multicolumn{4}{|c|}{ Female } \\
\hline & & AIC & RMSE & BIC & Cor & AIC & MSE & BIC & Cor \\
\hline Logistic & 4 & 10612.37 & 90.10 & 12818.94 & 0.9994 & 12798.8 & 67.75 & 10631.56 & 0.9990 \\
\hline Gompertz & 4 & 10632.73 & 92.13 & 12791.34 & 0.9992 & 12771.2 & 66.92 & 10651.91 & 0.9994 \\
\hline Brody & 4 & 11193.74 & 126.01 & 13409.36 & 0.9863 & 13389.22 & 87.17 & 11212.92 & 0.9888 \\
\hline Bridges & 5 & 10603.37 & 90.53 & 12789.89 & 0.9996 & 12764.71 & 66.67 & 10627.34 & 0.9994 \\
\hline Janoschek & 5 & 10603.37 & 90.53 & 12789.89 & 0.9996 & 12764.71 & 66.67 & 10627.34 & 0.9994 \\
\hline Richards & 5 & 10596.39 & 90.18 & 12776.06 & 0.9997 & 12750.89 & 66.27 & 10620.37 & 0.9996 \\
\hline
\end{tabular}

AIC: Akaike's information criterion, RMSE: Root mean square errors, BIC: Bayesian information criterion, MSE: Mean square errors, Cor: Pearson's correlation between predicted and actual body weights. The smallest and biggest values were highlighted in bold

Table 5. Estimated parameters of fitted models for males and females.

\begin{tabular}{|c|c|c|c|c|c|c|c|c|}
\hline Model & Sex & $\alpha(g)$ & $\beta$ & k (g/week) & $\mathbf{m}$ & $\mathrm{BW}_{0}$ & $\begin{array}{c}\text { Age at } \\
\text { inflection } \\
\text { (week) }\end{array}$ & $\begin{array}{l}\text { Weight at } \\
\text { inflection } \\
\text { (g) }\end{array}$ \\
\hline \multirow[t]{2}{*}{ Logistic } & Male & $1516.7 \pm 7.89$ & $38.75 \pm 2.11$ & $0.41 \pm 0.01$ & - & - & 8.95 & 758.35 \\
\hline & Female & $1117.06 \pm 4.72$ & $28.52 \pm 1.28$ & $0.40 \pm 0.01$ & - & - & 8.29 & 558.53 \\
\hline \multirow[t]{2}{*}{ Gompertz } & Male & $1620.82 \pm 12.42$ & $6.46 \pm 0.21$ & $0.24 \pm 0$ & - & - & 7.63 & 596.33 \\
\hline & Female & $1181.7 \pm 6.9$ & $5.54 \pm 0.15$ & $0.25 \pm 0$ & - & - & 6.91 & 434.77 \\
\hline \multirow[t]{2}{*}{ Brody } & Male & $3238.72 \pm 186.76$ & $1.08 \pm 0.01$ & $0.04 \pm 0$ & - & - & - & - \\
\hline & Female & $1813.03 \pm 50.88$ & $1.11 \pm 0.01$ & $0.06 \pm 0$ & - & - & - & - \\
\hline \multirow[t]{2}{*}{ Bridges } & Male & $1480.59 \pm 14.66$ & - & $5.79 e-03 \pm 0.59 e-04$ & $2.53 \pm 0.06$ & $34.81 \pm 8.82$ & - & - \\
\hline & Female & $1101.95 \pm 10.16$ & - & $0.01 \pm 0$ & $2.26 \pm 0.05$ & $23.53 \pm 6.51$ & - & - \\
\hline \multirow[t]{2}{*}{ Janoschek } & Male & $1515.4 \pm 9.47$ & - & $2.69 \mathrm{e}-03 \pm 0.34 \mathrm{e}-03$ & $2.53 \pm 0.06$ & $34.81 \pm 8.82$ & - & - \\
\hline & Female & $1125.48 \pm 6.04$ & - & $0.01 \pm 0$ & $2.26 \pm 0.05$ & $23.53 \pm 6.51$ & - & - \\
\hline \multirow[t]{2}{*}{ Richards } & Male & $1550.8 \pm 12.96$ & $8.96 \pm 3.3$ & $0.33 \pm 0.02$ & $0.54 \pm 0.1$ & - & 8.46 & 696.88 \\
\hline & Female & $1150.98 \pm 8.06$ & $3.32 \pm 1.22$ & $0.30 \pm 0.01$ & $0.35 \pm 0.08$ & - & 7.51 & 487.58 \\
\hline
\end{tabular}

BW0-initial body weight in $\mathrm{kg} ; \alpha$-mature body weight in $\mathrm{g}$; $\mathrm{t}$-age in weeks; $\beta, \mathrm{k}$, and $\mathrm{m}$-parameters specific for the function; $\beta$ characterizes the first part of growth before the point of inflection; k describes the second part in which growth rate decreases until the animal reaches the asymptotic or mature weight $(\alpha), \mathrm{m}$ is the shape parameter determining the position of the curve point inflection.

age at the inflection (from 6.91 to 8.29 weeks) than males (from 7.63 to 8.95 weeks) (Table 5). A similar trend was also observed for the weight at the inflection. The result of a higher BW in males than females is consistent with our previous reports for Mia chicken (Nguyen Hoang et al., 2021) and other earlier studies for other breed chicken, such as Athens-Canadian population chickens (Aggrey, 2002) and indigenous Venda chickens (Norris et al., 2007) and local Italian chicken (Rizzi et al., 2013) and Shaobo, Huaixiang and Youxi Chicken (Zhao et al., 2015). The asymmetric weights $(\alpha)$ for Ri chicken were varied among models but generally lower than values reported for other breeds (Rizzi et al., 2013; Mata-Estrada et al., 2020). All the estimated $\alpha$ values from six models for females are lower than 3,657g for females (Narınc et al., 2010). These results simply indicate the lower mature BW of the Ria chicken compared to other chicken breeds worldwide.

The $\mathrm{k}$ values also varied among the models, with very low values of $\mathrm{k}$ were obtained for Brody, Bridges, and Janoschek models. The estimated $\mathrm{k}$ values from the
Gompertz model is 0.33 in males, and 0.30 in females were higher than the values of $\mathrm{k}=0.15$ ( $\mathrm{g} /$ week) for both sexes in Mia chicken in another study (Nguyen Hoang et al., 2021). Yang (2006) reported the values of 0.13 (g/week) for males and 0.14 (g/week) for females, which was lower than $\mathrm{k}$ values from the current studies. It is also important to note that very low estimated $k$ values were estimated in the Brody, Bridges, and Janoschek models (Table 5). The mature rate is important for the farmers to decide the management strategies; therefore, future studies require exploring its biology. Ri chicken had a closely estimated age and weight at the inflection as in the previous studies (Yang, 2006; Miguel et al., 2008; Rizzi et al., 2013; Mata-Estrada et al., 2020). The age at inflection points in the current studies higher than values reported by Zhao et al. (2015), in chicken breeds raised in China (5.11 to 6.16 weeks) using similar models. However, these estimated values for Ri chicken were lower than values obtained in several worldwide breeds (Yang, 2006; Miguel et al., 2008; Rizzi et al., 2013; Mata-Estrada et al., 
2020). Genetics, nutrition, and environmental conditions are possible reasons for the variation among the results. Although the results of the Richard models are promising, further studies are required to estimate the heritability of the identified growth curve parameters and their genetic correlations with other economically important traits for further implementation of genetic/genomic selection for improvement of production traits in Ri chicken.

\section{Conclusion}

The models with four parameters showed the better performance compared to the models containing three parameters to describe the growth curve in Ri chicken and the Richards model is the most appropriate for the current $\mathrm{R}$ chicken population. Obtained information on the growth characteristics of Ri chicken in the current study might be used for management strategies and further genetic or genomic research.

\section{References}

AGGREY, S.E., 2002. Comparison of three nonlinear and spline regression models for describing chicken growth curves. Poultry Science, vol. 81, no. 12, pp. 1782-1788. http://dx.doi. org/10.1093/ps/81.12.1782. PMid:12512566.

BERTHOULY-SALAZAR, C., ROGNON, X., VAN, T.N., GÉLY, M., CHI, C.V., TIXIER-BOICHARD, M., BED'HOM, B., BRUNEAU, N., VERRIER, E., MAILLARD, J.C. and MICHAUX, J.R., 2010. Vietnamese chickens: a gate towards Asian genetic diversity. BMC Genetics, vol. 11, no. 1, pp. 53. http://dx.doi.org/10.1186/1471-2156-11-53. PMid:20565868.

DARMANI KUHI, H., PORTER, T., LÓPEZ, S., KEBREAB, E., STRATHE, A.B., DUMAS, A., DIJKSTRA, J. and FRANCE, J., 2010. A review of mathematical functions for the analysis of growth in poultry. World's Poultry Science Journal, vol. 66, no. 2, pp. 227-240. http://dx.doi.org/10.1017/S0043933910000280.

DO, D.N. and MIAR, Y., 2019. Evaluation of growth curve models for body weight in American Mink. Animals (Basel), vol. 10, no. 1, pp. 22. http://dx.doi.org/10.3390/ani10010022. PMid:31877627.

DO, D.N., HU, G., SALEK ARDESTANI, S. and MIAR, Y., 2021. Genetic and phenotypic parameters for body weights, harvest length, and growth curve parameters in American mink. Journal of Animal Science, vol. 99, no. 3, pp. skab049. http://dx.doi.org/10.1093/ jas/skab049. PMid:33585905.

ELZHOV, T.V., MULLEN, K.M., SPIESS, A.-N., BOLKER, B., MULLEN, M.K.M. and SUGGESTS, M., 2016 [viewed 12 March 2021]. Package 'minpack.lm'. R Interface to the Levenberg-Marquardt Nonlinear Least-Squares Algorithm Found in MINPACK, Plus Support for Bounds [online]. Available from: https://cran. rproject. org/ web/packages/minpack. lm/minpack. lm. pdf

GARCÍA-MUÑIZ, J.G., RAMÍREZ-VALVERDE, R., NÚÑEZ-DOMÍNGUEZ, R. and HIDALGO-MORENO, J.A., 2019. Dataset on growth curves of Boer goats fitted by ten non-linear functions. Data in Brief, vol. 23, pp. 103672. http://dx.doi.org/10.1016/j.dib.2019.01.020. PMid:30805424.

FOOD AND AGRICULTURE ORGANIZATION OF THE UNITED NATIONS FAO, 2020 [viewed 5 November 2020]. Domestic Animal Diversity Information System (DAD-IS) [online]. Available from: https:// www.fao.org/dad-is/browse-by-country-and-species/en/-.
IBEAGHA-AWEMU, E.M., PETERS, S.O., BEMJI, M.N., ADELEKE, M.A. and DO, D.N., 2019. Leveraging available resources and stakeholder involvement for improved productivity of African livestock in the era of genomic breeding. Frontiers in Genetics, vol. 10, pp. 357. http://dx.doi.org/10.3389/fgene.2019.00357. PMid:31105739.

IQBAL, F., EYDURAN, E., MIKAIL, N., SARIYEL, V., HUMA, Z., AYGÜN, A. and KESKIN, İ., 2019. A Bayesian approach for describing the growth of Chukar partridges. Archiv für Geflügelkunde, vol. 83. http://dx.doi.org/10.1399/eps.2019.284.

KAPLAN, S. and GÜRCAN, E.K., 2018. Comparison of growth curves using non-linear regression function in Japanese quail.Journal of Applied Animal Research, vol. 46, no. 1, pp. 112-117. http:// dx.doi.org/10.1080/09712119.2016.1268965.

MATA-ESTRADA, A., GONZÁLEZ-CERÓN, F., PRO-MARTÍNEZ, A., TORRES-HERNÁNDEZ, G., BAUTISTA-ORTEGA, J., BECERRILPÉREZ, C.M., VARGAS-GALICIA, A.J. and SOSA-MONTES, E., 2020. Comparison of four nonlinear growth models in Creole chickens of Mexico. Poultry Science, vol. 99, no. 4, pp. 1995-2000. http://dx.doi.org/10.1016/j.psj.2019.11.031. PMid:32241482.

MIGUEL, J.A., CIRIA, J., ASENJO, B. and CALVO, J., 2008. Effect of caponisation on growth and on carcass and meat characteristics in Castellana Negra native Spanish chickens. Animal, vol. 2, no. 2, pp. 305-311. http://dx.doi.org/10.1017/S1751731107001127. PMid:22445025.

MOULA, N., DANG, P.K., FARNIR, F., TON, V.D., BINH, D.V., LEROY, P. and ANTOINE-MOUSSIAUX, N., 2011. The Ri chicken breed and livelihoods in North Vietnam: characterization and prospects. Journal of Agriculture and Rural Development in the Tropics and Subtropics, vol. 112, no. 1, pp. 57-69. [JARTS]

NARINC, D., AKSOY, T., KARAMAN, E. and CUREK, D.I., 2010. Analysis of fitting growth models in medium growing chicken raised indoor system. Trends in Animal and Veterinary Sciences, vol. 1, no. 1, pp. 12-18.

NARINC, D., KARAMAN, E., FIRAT, M.Z. and AKSOY, T., 2010. Comparison of non-linear growth models to describe the growth in Japanese quail. Journal of Animal and Veterinary Advances, vol. 9, no. 14, pp. 1961-1966. http://dx.doi.org/10.3923/ javaa.2010.1961.1966.

NARINÇ, D., NARINÇ, N.Ö. and AYGÜN, A., 2017. Growth curve analyses in poultry science. World's Poultry Science Journal, vol. 73, no. 2, pp. 395-408. http://dx.doi.org/10.1017/ S0043933916001082.

NGUYEN HOANG, T., DO, H.T.T., BUI, D.H., PHAM, D.K., HOANG, T.A. and DO, D.N., 2021. Evaluation of nonlinear growth curve models in the vietnamese indigenous Mia chicken. Animal Science Journal, vol. 92, no. 1, pp. e13483. http://dx.doi.org/10.1111/ asj.13483. PMid:33462943.

NORRIS, D., NGAMBI, J., BENYI, K., MAKGAHLELE, M., SHIMELIS, H. and NESAMVUNI, E., 2007. Analysis of growth curves of indigenous male Venda and Naked Neck chickens. South African Journal of Animal Science, vol. 37, no. 1, pp. 21-26.

OSEI-AMPONSAH, R., KAYANG, B., NAAZIE, A., BARCHIA, I. and ARTHUR, P., 2014. Evaluation of models to describe temporal growth in local chickens of Ghana. Iranian Journal of Applied Animal Science, vol. 4, no. 4, pp. 855-861.

PADHI, M.K., 2016. Importance of indigenous breeds of chicken for rural economy and their improvements for higher production performance. Scientifica, vol. 2016, pp. 2604685. http://dx.doi. org/10.1155/2016/2604685. PMid:27144053.

PHAM, M., BERTHOULY-SALAZAR, C., TRAN, X., CHANG, W., CROOIJMANS, R., LIN, D., HOANG, V., LEE, Y., TIXIER-BOICHARD, M. and CHEN, C., 2013. Genetic diversity of V ietnamese 
domestic chicken populations as decision-making support for conservation strategies. Animal Genetics, vol. 44, no. 5, pp. 509-521. http://dx.doi.org/10.1111/age.12045. PMid:23714019.

R DEVELOPMENT CORE TEAM, 2011. R: A language and environment for statistical computing. Vienna, Austria: R Foundation for Statistical Computing.

RIZZI, C., CONTIERO, B. and CASSANDRO, M., 2013. Growth patterns of Italian local chicken populations. Poultry Science, vol. 92, no. 8, pp. 2226-2235. http://dx.doi.org/10.3382/ps.2012-02825. PMid:23873574.

SARIYEL, V., AYGUN, A. and KESKIN, I., 2017. Comparison of growth curve models in partridge. Poultry Science, vol. 96, no. 6, pp. 16351640. http://dx.doi.org/10.3382/ps/pew472. PMid:28204676.

SAWAI, H., KIM, H.L., KUNO, K., SUZUKI, S., GOTOH, H., TAKADA M., TAKAHATA, N., SATTA, Y. and AKISHINONOMIYA, F., 2010. The origin and genetic variation of domestic chickens with special reference to junglefowls Gallus g. gallus and G. varius. PLoS One, vol. 5, no. 5, pp. e10639. http://dx.doi.org/10.1371/ journal.pone.0010639. PMid:20502703.

SELVAGGI, M., LAUDADIO, V., DARIO, C. and TUFARELLI, V., 2015 Modelling growth curves in a nondescript Italian chicken breed: an opportunity to improve genetic and feeding strategies. Journal of Poultry Science, vol. 52, no. 4, pp. 288-294. http:// dx.doi.org/10.2141/jpsa.0150048.
SU, V.V., THIEN, N.V., NHIEM, D.T., LY, V.L., HAI, N.V. and TIEU, H.V., 2004. Atlas of farm animal breeds in Vietnam. Hanoi, Vietnam: Agricultural Publisher.

THORNTON, P.K., 2010. Livestock production: recent trends, future prospects. Philosophical Transactions of the Royal Society of London. Series B, Biological Sciences, vol. 365, no. 1554, pp. 28532867. http://dx.doi.org/10.1098/rstb.2010.0134. PMid:20713389.

THUY, L.T. and VANG, N.D., 2002. Present situation of animal genetic resources in Vietnam. In: Proceedings of the 10th NIAS International workshop on genetic resources, 11-12 December 2002, Tsukuba, Japan. Tsukuba, Japan: National Institute of Agrobiological Sciences, pp. 33-42.

WELLOCK, I., EMMANS, G. and KYRIAZAKIS, I., 2004. Describing and predicting potential growth in the pig. Animal Science (Penicuik, Scotland), vol. 78, no. 3, pp. 379-388. http://dx.doi. org/10.1017/S1357729800058781.

YANG, Y., 2006. Analysis of fitting growth models in Jinghai mixedsex yellow chicken. International Journal of Poultry Science, vol. 5, no. 6, pp. 517-521. http://dx.doi.org/10.3923/ijps.2006.517.521.

ZHAO, Z., LI, S., HUANG, H., LI, C., WANG, Q. and XUE, L., 2015. Comparative study on growth and developmental model of indigenous chicken breeds in China. Open Journal of Animal Sciences, vol. 5, no. 2, pp. 219-223. http://dx.doi.org/10.4236/ ojas.2015.52024. 